\title{
Developing Two-Year Apprenticeships in Norway and Switzerland
}

\section{Evi Schmid ${ }^{1}$ (1) $\cdot$ Ursula Scharnhorst $^{2} \cdot$ Marlise Kammermann $^{2,3}$}

Received: 3 March 2020 / Accepted: 15 July 2020 / Published online: 22 July 2020

(C) The Author(s) 2020

\begin{abstract}
Over the last 15 years, different countries have developed low-level vocational education and training (VET) programmes for young people who struggle to enter or complete education at upper secondary level. Switzerland introduced nationally standardised two-year initial VET programmes in 2005, Norway in 2016. Data of interviews with curriculum experts in Norway and Switzerland provided an empirical basis to examine the underlying intentions for offering these programmes and the respective criteria for defining the learning outcomes and the curricula. The reference frame in Norway for identifying appropriate learning outcomes and selecting learning goals are the national curricula of the respective four-year VET programmes. In Switzerland, the learning outcomes of two-year curricula are defined by lower-level occupational activities which are usually identified in analyses involving active workers and experts in the respective fields. Despite these differences, the criteria for developing two-year curricula are largely the same in both countries. The findings further show that two-year VET programmes in Norway are not intended to lead to a direct labour market entry but are understood as a first step of a staged qualification whereas in Switzerland they are designed to find a viable balance between employability and permeability to the more demanding three- or four-year VET programmes. In both countries, the twoyear apprenticeships do not correspond to a holistic concept of vocation.
\end{abstract}

Keywords Vocational education and training - Apprenticeship - Curriculum development . Youth at risk $\cdot$ Partial qualification

\author{
Evi Schmid \\ evis@oslomet.no \\ Ursula Scharnhorst \\ ursula.scharnhorst@sfivet.swiss \\ Marlise Kammermann \\ marlise.kammermann@sfivet.swiss
}

Extended author information available on the last page of the article 


\section{Introduction}

Low-achieving school leavers and young people at risk of dropping out from education at upper secondary level often need alternative and more flexible pathways to get a first VET qualification (OECD 2018b; Lamb 2011; Schmid 2020). Some countries have therefore developed low-level apprenticeship-based VET programmes, among them Denmark, Germany, Norway and Switzerland (Becker et al. 2017a; Di Maio et al. 2019; Schmid 2020). Norway and Switzerland offer two-year apprenticeships (at EQF ${ }^{1}$ level 3) for young people for whom a more demanding VET programme (mostly at EQF level 4) is still out of reach but try to ensure permeability to the latter. This study compares these apprenticeships on the basis of qualitative interviews tracing their overall intention and the goals and principles underlying the design of their curricula.

Two-year apprenticeships in Norway and Switzerland are interesting to compare for several reasons. Both approaches are targeted at the same population as both countries aim at implementing short-track apprenticeships for youth with low academic achievement who do not (yet) have the prerequisites to follow a more demanding VET programme. Both countries put an emphasis on practical in-company training but the shorter duration of these apprenticeships and the learning needs of the students imply that they have to be adapted with regard to the scope and level of the goals pursued.

However, there are some fundamental differences between the two approaches, mainly concerning the embedding of the two-year apprenticeships in the VET system and their recognition. In Switzerland, two-year apprenticeships have the same structure as three- and four-year apprenticeships; they are all dual apprenticeships where the apprentices spend three to four days per week at the workplace and one to two days at school. Two-year apprenticeships are thus part of the regular VET system and the certificates are regarded as an upper secondary qualification (Wettstein et al. 2017). In Norway, the two-year apprenticeships are organised differently than the longer, more demanding VET programmes. The latter follow the $2+2$ model combining two years of mainly school-based training with two years of apprenticeship training (Nyen et al. 2015) whereas in two-year apprenticeships the focus on in-company training is much stronger, with 4 days per week in a training company (Utdanningsdirektoratet 2017). Two-year apprenticeships are currently not recognised as an upper secondary qualification.

These differences raise questions about the intentions behind the introduction of two-year apprenticeships, their goals and underlying principles of curriculum design. Consequently, the article addresses the following research questions:

1. What are the main intentions for developing two-year apprenticeships in Norway and Switzerland?

2. Which criteria are used to define or select learning outcomes of two-year apprenticeships and to design the respective curricula?

These questions emphasise the interest in what is called the intended curriculum (Van den Akker 2003; Billett 2011) which relates to the vision, rationale or basic philosophy

\footnotetext{
${ }^{1}$ The European Qualification Framework (EQF) has 8 levels. VET qualifications are ranked by each country and may be at different levels (see European Commission 2020).
} 
underlying the curriculum (Van den Akker 2003) and refers to what is planned and intended by developers and stakeholders (Billett 2011). The conception behind the design of a curriculum has a considerable impact on how it is enacted and what learners experience and learn (Billett 2006).

In the next two sections, the theoretical framework is outlined. First, theories are presented which understand the design of an apprenticeship curriculum as sequencing the learning path to guide novice learners on their way to become competent workers. Second, from the perspective of a holistic concept of vocation, perceived chances and risks of modularisation and partial qualification are presented. Then, the VET systems of Norway and Switzerland are described, with a focus on two-year apprenticeships, and important similarities and differences are pointed out. Subsequently, the method of our interview study is described before presenting the findings to answer the research questions. Finally, the findings and potential implications for the VET systems are discussed and limitations of the study are pointed out.

\section{Designing an Apprenticeship Curriculum}

Given the importance of VET for the economic development of a country, the design of apprenticeship curricula has become a key concern of national VET agencies. In many countries, representatives from industry play a central role in determining the occupation-specific learning outcomes (competences). They define the occupationspecific learning aims, goals (and often the objectives), i.e. what and how it is to be taught and assessed and to what standard (Billett 2011). In brief, they design the "path of learning" (Chan 2017, p. 329) or the "track to be run" (Billett 2006, p. 35) by sequencing the work activities and shaping the experiences that learners progress along. Curriculum developers are therefore confronted with the question how to best design this path to create learning opportunities and support the acquisition of competences at the workplace and at vocational school. The theoretical framework chosen considers workplace learning as a sequenced pathway of activities towards vocational expertise and is also referred to as learning curriculum (Lave 1990), situated curriculum (Gherardi et al. 1998) or workplace curriculum (Billett 2001). These concepts are rooted in Lave and Wenger's (1991) conception of learning as participation in 'communities of practice'. They describe learning as the gradual transition from a marginal to a core position in the work team, from legitimate peripheral participation to full participation in the community of practice. They argue that it is participation in workplace activities and social interactions which enable novices to learn from more experienced practitioners. In line with other work, they emphasise that learning a trade is more than acquiring and developing a set of occupational skills. Learning is conceptualised as a process of gradually being socialised by and into work communities and a process of social participation (Lave and Wenger 1991), a process of becoming (Colley et al. 2003; Hodkinson et al. 2008) and of identity formation (Wenger 1998).

In workplaces, the sequencing of activities often follows the logic of increasing economic impact (Gherardi et al. 1998), with a movement from activities with low complexity, accountability and error costs to activities with higher accountability and complexity where errors have important consequences (Billett 2001; Gherardi et al. 1998; Lave 1990). Accordingly, the pathway from novice to expert participation may 
be structured from more routine to non-routine activities which require more complex and autonomous forms of problem-solving (Hatano and Inagaki 1986; Billett 2001).

To be responsible to execute tasks of increasing complexity it is essential for the learners' progression towards independent practice. Moreover, trust and a gradual release of responsibility allow apprentices to become recognised members of the work community and develop a sense of belonging and commitment (Reegård 2015). In the beginning, novices learn through observation, imitation, guided participation and practice (e.g. Lave 2011; Chan 2017; Rogoff 1995). At this stage, guidance, instruction and support from experienced others are central for their learning (Lave and Wenger 1991; Billett 2001; Collins et al. 1989), and insufficient support and guidance may cause stagnation of learning and isolation (Reegård 2015). Guidance may be provided directly or indirectly and includes techniques and strategies to direct and support learning processes as well as to monitor knowledge acquisition of the learners (Billett 2000). Guidance by more experienced others, instruction and feedback are gradually reduced as learners progress towards smooth execution of the whole task (Collins et al. 1989). A learning path along work activities and experiences of growing complexity and accountability hinges on the learners' ability and readiness to move on to more complex tasks or a more independent practice. It is part of a guide's role to organise learning opportunities and to guide learners by monitoring their participation in the workplace activities and determining their readiness to engage in activities of increasing accountability and autonomy (Billett 2001). Depending on the potential or the readiness of the learners, the gradual release of guidance and the increase in complexity of the assigned work tasks therefore takes more or less time and may eventually also be constrained.

On the macro and meso level, the structure of VET systems and their formalised programmes shape the described pathway to vocational expertise by defining which competence levels have to be attained to be a qualified worker and how this is to be achieved (i.e. duration of the programmes, learning locations, curricular frames).

\section{Concept of Vocation and Partial Qualification}

The described characteristics which shape workplace curricula and the socialisation of apprentices into a working community are in line with dual VET systems and labour markets that adhere to a holistic concept of vocation, not to a narrow, functional understanding of qualification. Gonon (2014) refers to this concept as decisive not only on a systemic level, but also for schools and firms as it influences the didactical and methodical structure of VET teaching and learning. Pilz and Canning (2017, p. 723 ) point out that a "traditional holistic vocational training course typically comprises a linear sequence of learning pathways as part of a coherent, over-arching area of study. Learning processes are linked to learning outcomes, so assessment and certification depend on students' participation in formal learning processes". Consequently, learning outcomes are assessed and certified upon completion of the training and cover the whole course. The holistic concept of vocation is also considered as crucial for a modern, more dynamic view of occupations which expects competent professionals to find creative and flexible solutions to problems (Rauner 2012).

It usually takes three to four years of apprenticeship to develop the competences corresponding to a holistic notion of vocation and the related processes of teaching, 
learning and socialisation cannot be modularised (INAP Commission 2012). Going through an apprenticeship "is a recognised and formalised route to achieving the relevant occupational expertise [...]" (Fuller 2016, p. 17) which implies that qualified workforce execute tasks in their whole process (Becker et al. 2017b). Competent professionals design, plan, perform and assess their own work activities, a performance level requiring metacognitive competences to cope with complex, unpredictable work situations (e.g. Rauner 2007). This type of adaptive expertise differs from only routinebased expertise (Hatano and Inagaki 1986). To become competent and responsible, situated learning in real work contexts as well as the need for self-directed and reflexive learning is considered as important (Dehnbostel and Schröder 2017).

The question arises if two-year apprenticeships for disadvantaged or weaker learners can meet the concept of vocation or if they have to be regarded as a partial qualification, a step on the way to a full qualification for the labour market. Di Maio et al. (2019) point to the tension between economic and social goals in shorter two-year apprenticeships that focus on theory-reduced applied training but should lead to standardised certificates. Their comparative analysis of the respective offers in Denmark, Germany and Switzerland shows that the institutionalisation of economic and social goals differ, depending on VET regulations, regional and sectoral standards, and legitimisation of the key actors.

Countries like Switzerland with a strong tradition of apprenticeships based on the concept of vocation are rather reserved with regard to strict forms of partial qualification (i.e. shorter, highly standardised modules that are separately assessed and credited to a final qualification), at least in initial VET. However, chances and risks of modularisation were repeatedly debated (in Switzerland, e.g. by Gonon 2009; Ghisla 2005; Häfeli 2005). Current debates reappear within broader strategies of VET systems for addressing future challenges posed by megatrends which influence the labour market and require more differentiation between learners in terms of prior knowledge and performance (e.g. Cedefop 2015; Pilz and Canning 2017; Seufert 2018).

In practice, moderate forms of modularisation have become common in dual VET systems as they offer more flexibility, for training companies as well as for individuals (e.g. Seufert 2018; Li and Pilz 2017; Cedefop 2015; Pilz 2012). According to Pilz (2012), supplementary, differential or divided forms of modularisation can be distinguished. Supplementary forms allow learners to expand their competences with additional modules. Differential forms break VET programmes down into components (e.g. elective skills modules) but the overarching concept of vocation and the final examinations are preserved (Li and Pilz 2017). Divided forms imply discrete learning units that are separately assessed and certified to substitute the final examinations. They are difficult to establish in initial VET where the final examination and the overall qualification are perceived as relevant (e.g. Li and Pilz 2017).

Several countries initially developed modularised pre-VET or VET programmes for disadvantaged or weaker students to help them engage in apprenticeships by setting adapted learning goals and qualifying them step-by-step to enhance their learning motivation, reduce dropout and recognise prior learning and progression (Cedefop 2015; Canning 1998). However, modularisation does not play an important role in two-year apprenticeships in Norway and Switzerland but the respective understanding of their certification is different. 


\section{Two-Year Apprenticeships in Norway}

The main VET model since the reform in 1994 is the so-called $2+2$ model: two years of school-based education followed by two years of apprenticeship training. Young people in Norway are legally entitled to three years of upper secondary education and to a place in one of three alternative programmes for which they apply. They may choose from five general academic programmes (e.g. specialization in general studies, art design and architecture) and ten VET programmes (e.g. building and construction, restaurant and food processing, healthcare, childhood and youth development) offered at the same schools. About $98 \%$ of the young people start upper secondary education immediately after compulsory school, half of them enrol in vocational programmes. However, due to dropout from VET and to changes from VET to general education, the proportion of young people graduating from VET below the age of 25 is much lower $(19,0 \%)$ than from general education $(61,2 \%)$ (OECD 2018a). Dropout from upper secondary education, especially from VET, has therefore been an educational policy issue for a long time. As one of several measures, the Ministry of Education and Research suggested in 2006 to implement a new two-year apprenticeship scheme (praksisbrevordning) aiming at a low-level of vocational competence. It was supposed to be a further development of the little used training candidate scheme introduced in 2001 (lærekandidatordning). In contrast to the training candidate scheme, which usually comprises two years of school followed by two years of in-company training and which is based on individual training plans, the new two-year apprenticeship scheme was conceived as a short-track VET programme focusing on in-company training. The respective curricula were supposed to be standardised and lead to a standardised vocational competence (Kunnskapsdepartementet 2006). Between 2008 and 2011, three counties trialled two-year apprenticeships in different VET programmes which were evaluated as "a very successful measure to reduce dropout" (Høst 2016, p. 16). In 2016, the two-year apprenticeship scheme was nationally introduced as a certificate corresponding to a 'documented partial competence', one of three possible forms of qualification at upper secondary level (Section 3-3 of the Norwegian Education Act). 'Documented partial competence' is at a lower level (EQF level 3) than full vocational or university admission certification and does not correspond to a certification at upper secondary level. After completion of a two-year apprenticeship, apprentices may continue their training to obtain a full trade certificate (EQF level 4) (Utdanningsdirektoratet 2017).

Four days a week, apprentices in two-year apprenticeships are trained in a company, one day a week, they attend vocational school. During this weekly school day, they are taught in three of the common core subjects (i.e. Norwegian, mathematics, social sciences) where full goal achievement is required (equivalent to regular VET programmes). Unlike students in regular VET programmes, however, apprentices in two-year apprenticeships are not taught in the common core subjects English and natural sciences, nor are they taught in occupation-specific subjects at school (Utdanningsdirektoratet 2017).

In contrast to the longer VET programmes, in which the occupation-related goals are based on national curricula for the two years at school and for the two years of incompany training, the two-year apprenticeships are based on local curricula. The Norwegian Directorate for Education and Training decreed that counties offer a two- 
year apprenticeship in at least one VET programme. The intention was to meet the local need for skills and to ensure that the apprentices build up competences needed in working life (Utdanningsdirektoratet 2017). Therefore, the county authorities, together with local businesses and industries, decide which programmes are offered. According to the regulations, the competence goals of the two-year apprenticeships must be selected from the national curricula of the corresponding VET programme and be kept identically but the counties are free to select goals they consider as adequate for regional implementation. This means that the competence goals chosen for two-year apprenticeships are always a subset of the occupation-specific goals that are defined in the school-based and work-based national curricula of the corresponding four-year VET programme.

The two-year apprenticeship schemes have not yet been evaluated since their national introduction and no overview of the developed curricula is available. In October 2018, 45 apprentices were enrolled, half of them in the retail sector (personal communication of Statistics Norway).

\section{Two-Year Apprenticeships in Switzerland}

With about two thirds of young people enrolling in VET programmes at upper secondary level, Switzerland has one of the highest proportions in initial VET across OECD countries and the EU (OECD 2018a). About 90\% of the students in VET enrol in apprenticeship-based programmes in which education and training take place in three learning locations: training companies, vocational schools and branch training centres (Wettstein et al. 2017).

Standard VET programmes take two, three or four years and are offered in approximately 230 occupations. Graduates of three- or four-year VET programmes (EQF level 4 or 5) may continue their education and training in higher VET. The less demanding two-year apprenticeships (zweijährige berufliche Grundbildungen) lead to a Federal VET Certificate (EBA) at EQF level 3. These certificates are considered as a full but low-level occupational qualification at upper secondary level.

Originally, two-year VET programmes (Anlehren) for young people with low academic achievement were introduced in the Vocational Education and Training Act of 1978. They were not standardised and only recognised at county level but could be individually adapted. Their lack of standardisation was considered as a dead end, by the youth and their parents as well as by employers. They made up only 1 to $2.5 \%$ of all apprenticeship contracts (Kammermann 2017). Standardised and nationally recognised two-year apprenticeships for low-achieving or disadvantaged youth were introduced in the Vocational and Professional Education and Training Act (VPETA) of 2002 (Swiss Confederation 2002). If successful completion of these programmes is jeopardised, the VPETA foresees individual support measures.

Two-year apprenticeships should enhance the integration into the labour market by ensuring a comparable level of competence of the graduates through standardised training plans and final examinations. The intention is to train skilled workers for simple occupations not requiring complex decisions. At the same time, permeability is ensured by crediting one year at the most to the corresponding three- and four-year VET programmes, an option which is accorded to one-third of the apprentices who continue (Der Bundesrat 2019). 
Professional organisations are responsible for developing the nationally standardised VET programmes. They determine the duration and requirement level of the programmes in their occupational field and define the occupation-specific learning outcomes. They also decide whether a two-year apprenticeship is developed and thereby ensure its acceptance in the labour market. Each of the 230 VET programmes is regulated in a respective ordinance and a training plan. The training plan is the curriculum specifying the occupational learning goals for all learning locations. Modular differentiations (i.e. functional specialisations (Fachrichtungen) or emphases (Schwerpunkte) and elective skills modules (Wahlmodule)) after a basic common trunk are common, mainly in three- or four-year apprenticeships. Also $20 \%$ of the two-year apprenticeships have functional specialisations or emphases but they are chosen from the start.

Apprentices in two-year VET programmes are four days per week in the company and one day at school. Half of the weekly school day is dedicated to occupational subject matters, the other half to general education. For the latter, the framework for general education in initial VET applies which relates to competences in language, communication and society that are taught in three weekly lessons (plus a lesson of sport).

The first two-year apprenticeships started in 2005 and since then, just under 60 programmes were developed (with few of them not offered anymore). The number of enrolments grew steadily and in 2018, two-year apprenticeships made up $6.5 \%$ of all initial VET programmes (BFS 2019). Considering all upper secondary certifications awarded (including general education) in 2015, the two-year apprenticeships made up $5.9 \%$ (BFS 2018).

The two-year apprenticeships have been evaluated and prove to be quite successful: two-thirds of the graduates enter the labour market and about one-third continue their education and training (e.g. Kammermann et al. 2011; Der Bundesrat 2019).

\section{Main Similarities and Differences between the Two Countries}

The following Table 1 summarises the main intentions and characteristics of two-year apprenticeships in Norway and Switzerland.

\section{Method}

To answer our research questions, we conducted semi-structured interviews with experts that are involved in developing two-year VET curricula in Norway and Switzerland. As two-year apprenticeships are regulated and implemented differently in the two countries, appropriate and comparable interview partners had to be selected. We were looking for persons who participate in the construction of two-year curricula but who are also familiar with the reality of their implementation. The interview procedures were as identical as possible to ensure comparison of results.

In Norway, the counties are responsible for implementing the two-year apprenticeships but so far there exists no overview of the offered two-year programmes and their curricula. A short email survey was therefore conducted in all 18 counties $^{2}$ in October

\footnotetext{
$\overline{2}$ Since January 2020 the number of counties is reduced to eleven.
} 
Table 1 Overview of similarities and differences in two-year apprenticeships between Norway and Switzerland

\begin{tabular}{|c|c|c|}
\hline & Norway & Switzerland \\
\hline \multicolumn{3}{|l|}{ Similarities } \\
\hline Targeted population & $\begin{array}{l}\text { Low academic achievement, Youth at } \\
\text { risk }\end{array}$ & Low academic achievement, Youth at risk \\
\hline In-company training & 4 days per week & 4 days per week \\
\hline Training at school & 1 day per week & 1 day per week \\
\hline EQF qualification & Level 3 & Level 3 \\
\hline $\begin{array}{l}\text { Permeability to EQF } \\
\text { level } 4-5\end{array}$ & $\begin{array}{l}\text { Possible with } 2 \text { additional years of } \\
\text { in-company training }\end{array}$ & $\begin{array}{l}\text { Possible to start in the } 2 \text { nd year of the } \\
3-/ 4 \text {-year VET programme }\end{array}$ \\
\hline \multicolumn{3}{|l|}{ Differences } \\
\hline Governance & Regional & National \\
\hline $\begin{array}{l}\text { Occupation-specific } \\
\text { curricula }\end{array}$ & For in-company training & $\begin{array}{l}\text { For in-company training, for school and for } \\
\text { branch training centres }\end{array}$ \\
\hline $\begin{array}{l}\text { Subject matters at } \\
\text { school }\end{array}$ & $\begin{array}{l}\text { High emphasis on general subject } \\
\text { matters }\end{array}$ & $\begin{array}{l}\text { High emphasis on occupational-specific } \\
\text { subject matters }\end{array}$ \\
\hline Qualification & Documented partial competence & Full qualification \\
\hline
\end{tabular}

2019 to ask the county municipalities whether or not they currently have apprentices in two-year apprenticeships and whether they have developed curricula. This allowed to identify all the responsibles for the implementation in the counties. So far, five counties had apprentices since 2016. All five responsibles could be interviewed. Together with the involved companies they have developed two-year curricula and are overseeing their implementation. Two interviews were conducted face-to-face, three interviews by phone, with an average interview duration of $30 \mathrm{~min}$. All interviews were conducted between October and November 2019.

In Switzerland, two-year apprenticeships are nationally standardised and the curricula are developed in a process prescribed by the national VET agency (SBFI 2017) in which the professional associations need to work with an accredited pedagogical consultant. In Switzerland three experienced pedagogical consultants who have been involved in the development of two-year VET curricula since their introduction were interviewed. All of them have consulted in the development of several two-year curricula and know the challenges involved. As they were VET teachers themselves for many years, they also know the VET system from inside. The interviews were held face-to-face, between October and December 2019, with an average duration of $50 \mathrm{~min}$.

The interviews focused on 16 key questions which comprise three groups of questions: First, the reason for implementing two-year apprenticeships and their process of development (governance and organisational aspects; e.g. "How was the need for a specific two-year apprenticeship identified?"). Second, the development of the curricula and the underlying conceptual ideas and strategies (paths of learning to vocational expertise; e.g. "Which criteria define the curricula? Which criteria are used to define learning outcomes?'). Third, the overall intention and the embedding of twoyear apprenticeships (stand-alone occupation vs. partial qualification; e.g. "What professional competence do the two-year apprenticeships lead to?"). These questions 
emerge from the chosen theoretical framework and were adapted to the countryspecific situation.

All of the interviews were audiotaped, transcribed verbatim and personal information was anonymised. The first analysis step consisted of a data driven construction of codes (Gibbs 2018). Reliability of coding was ensured on a subset of statements coded by several raters. In a second step, we assigned the codes to six categories or dimensions which relate to the theoretical framework and the systemic characteristics: (1) occupation-specific core elements, (2) reducing complexity, (3) limiting accountability and autonomy, (4) considering the economic setting, (5) reducing the scope of the occupational profile, and (6) work- vs. school-based goals. All quotations illustrating these dimensions were translated.

\section{Findings}

First, the research question regarding the intentions for developing a two-year apprenticeship is addressed. Second, the commonalities and differences in the definition of learning outcomes and the design of curricula in two-year apprenticeships found between Norway and Switzerland are presented along the six dimensions outlined above.

\section{Research Question 1}

\section{Main Intentions of Two-Year Apprenticeships}

This section takes up our first research question concerning the intention for developing two-year apprenticeships. It is closely linked to the perceived significance and value of the vocational qualification awarded with a two-year certificate. In both countries twoyear apprenticeships are intended to enable youth with difficulties to access or complete upper secondary education and to obtain a qualification. The awarded qualification should ensure its holders to either enter the labour market or to continue education and training. This means that the acquired competences should match with labour market needs and, at the same time, ensure permeability towards more demanding VET programmes. In Switzerland, both goals are decidedly pursued as stated by all the interviewees, e.g.: "From the beginning it was stated that these are stand-alone occupational profiles. They [the learners] should get the possibility to subsequently experience permeability" (Swiss quotation). Or similarly:

"The mission was clear, namely to develop a stand-alone occupational profile, this means to develop an occupation which is not a partial qualification, nor an introductory qualification to something, but to develop an occupation, a two-year basic training, which after completion leads to an employment, a job which can be competently done" (Swiss quotation).

In Norway, the transition into the labour market after two years is not envisioned by the counties but the national goal of permeability to the regular VET programmes is 
crucial. This applies to all five counties in which curriculum responsibles were interviewed:

"You know, the signal we get from the world of work is that the training practice certificate [two-year certificate] as a final qualification is not interesting but as a pathway to the regular trade or journeyman's certificate [full, four-year certificate]" [...] But in [county] this never was an issue. Nobody ever talked about this. It is only a pathway to obtain a regular occupational certificate" (Norwegian quotation).

This means, in all five counties the two-year apprenticeships are regarded as the first stage of a four-year qualification for which the two-year certificate is an intermediate milestone: "So it takes them four years. But we count two years as one block" (Norwegian quotation). In this sense, one could speak of a partial qualification. This understanding is promoted and the recruiting of apprentices is handled accordingly, so it is clear to all from the very start that they take up a staged four-year programme: "I find that selling it [two-year programme] as something on which you can live all your life is almost like fooling people" (Norwegian quotation).

Given the intention of a staged qualification, the educational authorities have apprentices for two-year apprenticeships in mind "who do not have learning difficulties or special training needs" [...] but "who may have poor grades, high school-absence" (Utdanningsdirektoratet 2017, p. 1). The interviewees emphasised that the target group are mainly school-weary youth for whom a more practical training in a company at the beginning is more suitable than two school-based years.

Switzerland follows a different logic: two-year apprenticeships are intended for learners who do not (yet) have the necessary academic skills for a three- or four-year programme but need a more practically oriented VET offer. But they have the option to continue in a more demanding three- or four-year programme if they thrive and graduate with good marks.

"Only few have this goal [to continue training]. Others are people that are thankful in their occupation, and that they can work at a workplace where they live $[\ldots]$ years later, when I meet them, they are still satisfied with the job they have because they feel it is adequate" (Swiss quotation).

Overall, two thirds of the graduates enter the labour market and about one third continues education and training (Der Bundesrat 2019; Kammermann 2017).

\section{Research Question 2}

\section{Dimension 1: Occupation-Specific Core Elements}

In both countries interviewees underlined that occupation-specific core elements need to be acquired regardless of the duration and the level of qualification of the respective training. This shows in statements from Norwegian interviewees like "this is the bottom line from which we cannot deviate" or "this was clearly evident. It was no subject of 
discussions". So, even if a low level of competence (EQF level 3) is envisioned in twoyear apprenticeships, certain occupational activities or functions (core competences) have to be fulfilled and, consequently, the necessary knowledge, skills and attitudes need to be acquired. Such core competences are typically formulated in brief descriptions of occupations based on the concept of vocation (e.g. INAP Commission 2012). Other mentioned core elements, often found across occupations in the same field, concern aspects like work security, ergonomics and health protection or confidentiality with respect to client relations.

\section{Dimension 2: Reducing Complexity}

An important strategy in designing two-year curricula repeatedly mentioned in the interviews is to reduce the complexity of the competences to be trained in comparison to the VET programmes with a longer duration and higher outcome expectations. This is illustrated by the following statements:

"In construction you may, for example, participate in window installation but you don't need to be able to line windows and protect them with a bar on the outside front $[. .$.$] . So they participate but this won't be part of their final exams as it is$ rather advanced" (Norwegian quotation).

"Or when you think of cooking, it may be limited to assemble salad bowls [...] but he won't make very elaborated salad buffets [...]. The workplace is the same, the essential activities are the same, or, the feeling is the same" (Swiss quotation).

These statements emphasise that the complexity of work activities may be reduced without restricting the learners' social participation as it is described in the concept of legitimate peripheral participation (Lave and Wenger 1991). Complexity reduction is often achieved by focusing on the acquisition of routine-based expertise rather than on complex tasks requiring conscious and reflective problem solving (e.g. Hatano and Inagaki 1986; Billett 2001). On the emotional level, however, the demands to be met may be the same as those for learners of the longer, more demanding VET programmes:

"This learner in health and social care is exposed to emotional situations of the same complexity as every care professional. And it is particularly the emotional complexity that is very, very demanding in the care of elderly people and persons with handicaps" (Swiss quotation).

This statement reminds of arguments that complexity is not only defined by cognitive requirements (e.g. Krathwohl et al. 1964) and it also refers to the above-mentioned occupation-specific core elements.

\section{Dimension 3: Limiting Accountability and Autonomy}

In addition to the reduction of task complexity, the interviewees emphasised that the degree of self-regulation and accountability has to be reduced in two-year programmes: 
"In the description of the targeted competences it often says 'with guidance', 'in cooperation with', it is to say there are activities which a social and health care worker can do alone but these tasks are delegated to her. So she [...] often acts in delegation" (Swiss quotation).

Limited self-regulation and accountability automatically call for more and closer support, for guidance and supervision of work activities during training (Collins et al. 1989). According to the interviewees, support and guidance are provided in the twoyear apprenticeships in Norway and Switzerland. However, limited autonomy and accountability may be characteristic for the level of qualification that can possibly be achieved in two years with disadvantaged learners as expressed by a Norwegian interviewee: "I don't believe that you can work alone in a kitchen and be an independent 'à la carte cook' after two years of training" (Norwegian quotation). If so, questions regarding the value of a two-year qualification arise: Is it sufficient for a stand-alone occupation for which there is a demand in the labour market or is it necessarily only a partial qualification? This refers to the issue of partial vs. full qualification and to the difficulty to accept partial qualifications in strong dual VET systems (e.g. Li and Pilz 2017).

\section{Dimension 4: Considering the Economic Setting}

Both countries consider labour market demands in designing two-year apprenticeships by getting direct information on the envisioned workplace settings but the respective efforts differ in scope and systematicity.

In Switzerland, the process of developing training plans for two-year apprenticeships is highly standardised and a crucial part is the "analysis of the occupational activities" (Zbinden 2010). It is based on workshops involving young workers who represent different types of enterprises (e.g. small, medium, large, generalists, specialists) in the respective occupational field but also experts who know the current and future demands at different levels of qualification.

"The activities [collected and described] are grouped into domains; out of this, a profile of occupational competences or a qualification profile giving an overview of the occupational competences is generated in the end. Thus, the occupational profile is described along with the level of requirement" (Swiss quotation).

In Norway, the standard national VET curricula are developed in a similar way. In contrast, it was determined that the curricula of the two-year apprenticeships should be developed with the local businesses and industries in order to meet local skills needs (Utdanningsdirektoratet 2017). Due to the still very limited number of youth in twoyear apprenticeships, individualised procedures are favoured as it showed in the interviews: the county authorities contact single companies willing to train and directly get information about workplace settings. On this basis, workplace-specific competence goals are defined for training.

"Yes, it is the companies that looked at this, in cooperation with the branch specialist of the regional authority. And they looked what was possible within half of the 
training [referring to the standard duration of VET programmes], and what they can achieve, and based on this, they choose the goals" (Norwegian quotation).

Although the programmes are supposed to be standardised, they may end up being wholly individualised if they are conceived for a specific workplace and a specific learner. This happens in counties which offer several two-year apprenticeships but only have single learners interested in them: "So we select what is practically realisable, depending on the prerequisites of the boy and the working tasks in the given company, plain and simple" (Norwegian quotation).

\section{Dimension 5: Reducing the Scope of the Occupational Profile}

This dimension refers to the reduction of the number of competence areas covered in two-year apprenticeships, not to their level of complexity. It seems to be especially relevant in Switzerland where two-year VET certificates should qualify their holders for simple, yet stand-alone occupations but also offer them the possibility to continue education and training. There are two issues to be considered: the first is whether there is a stable labour market demand for more limited competence profiles; the second concerns the permeability which might be restricted if a two-year curriculum does not take enough competence areas of the corresponding more demanding VET programme into account. A few examples of too narrowly conceived two-year apprenticeships and the respective consequences were mentioned in the interviews (e.g. information technology assistants): “[...] very many, or practically all [learners], subsequently started a four-year apprenticeship because there was absolutely no market for the two-year graduates. It was like too narrow, the spectrum they learned there, to match with the labour market" (Swiss quotation).

This shows that too narrow profiles might not correspond to labour market needs. The two-year apprenticeship for information technology assistants was therefore given up by the professional organisation. However, some of the two-year curricula differentiate functional specialisations within the occupational profile from the start. This helps to reduce the scope of a curriculum and, at the same time, accommodates the specialised structures of training providers (e.g. Pilz 2012).

In Norway, the scope of two-year apprenticeships also has to be limited but the reference frame for selecting the competence areas are the four-year programmes. In fact, the interviewees reported that they are supposed to select between one third and one half of the learning goals of the corresponding four-year curricula to define the two-year curricula. The national authority left open whether this reduction is achieved by focusing on a broad and general qualification profile or a narrow, specialised one (Utdanningsdirektoratet 2017). Given the fact that the curricula have not been standardised up to now, it is not known to what degree the two possibilities are realised. In any case, the graduates of two-year apprenticeships are expected to continue their education and training.

\section{Dimension 6: Work-Based Vs. School-Based Goals}

This dimension is relevant in Norway because the two-year apprenticeships follow a dual-track model (4 days per week at work, 1 day at school) which differs from 
the regular $2+2$ model ( 2 years of school-based training followed by 2 years of apprenticeship). It was already mentioned that the goals for two-year curricula have to be selected from the respective four-year curricula. This poses the challenge that two school-based curricula (used during the first two years) and a workbased curriculum (used for the apprenticeship training) are the reference points for defining the work-based curricula of the two-year apprenticeships. Different interviewees said that the apprenticeship curriculum of the $2+2$ model is usually the first reference for defining the two-year curriculum. Only in the second step, a subset of the corresponding school-based goals of the first two years are selected to make a coherent whole, which means that certain school-based goals are sorted out for being too theoretical: "It should eventually be connected" (Norwegian quotation).

\section{Discussion and Conclusion}

This study examines the conception and implementation of two-year apprenticeships in Norway and Switzerland and shows that they differ in various aspects. It also finds common criteria in the development of the curricula in both countries. In Switzerland, the mandatory analyses of occupational activities for the development of VET curricula ensure that occupational profiles at different requirement levels are identified. If the depth and breadth of the activities in a vocational field are substantial, it is possible to create a two-, a three- and a four-year programme. This approach leads to the conception of low-level stand-alone occupations with a specific title which ensure employability but also permeability to the more demanding VET programmes. In contrast, in Norway the prescribed basis for defining the learning outcomes and the curricula of two-year programmes are the existing four-year curricula. The two-year programmes therefore represent a part of the fully qualifying four-year programmes. Consequently, they cannot be recognised as stand-alone occupations, and they do not have specific titles so far. This corresponds to a staged vision of qualification and successful completion of a two-year apprenticeship does not lead to a certification at upper secondary level.

In both countries, the competences attainable in two-year apprenticeships hardly correspond to a holistic concept of vocation (Becker et al. 2017b; Fuller 2016; INAP Commission 2012) as the learning outcomes and curricula have to be adapted to the target population. The expectations regarding complexity, responsibility and autonomy which are envisioned in a holistic concept of vocation and in an apprenticeship curriculum (Billett 2001; Gherardi et al. 1998; Lave 1990) cannot be met in two years. This brings us back to the main intention behind the development and implementation of two-year apprenticeships, namely to include low-achieving school leavers and youth at risk of dropping out of upper secondary education. In Switzerland, this goal seems to be fulfilled. Holders of a two-year certificate have accomplished a nationally standardised labour market-oriented programme, are employable and can continue their education and training in a three- or four-year VET programme. On the whole, the labour market integration after two years (two-thirds of the graduates) but also the permeability to the more demanding VET programmes (one-third) are considered as a success (Der Bundesrat 2019). 
The two-year curricula are also standardised in Norway but at the regional level. The transition to the labour market after two years is not envisioned by the counties. The county responsibles for two-year apprenticeships emphasise that there is no need for this kind of vocational qualification in the labour market. However, the original intention of the national authority implied to encourage permeability as well as employability (Utdanningsdirektoratet 2017). But almost all apprentices continue their education and training after having obtained a two-year certificate to acquire a full trade certificate. Also the evaluation of the trial period reported a high permeability (Høst 2016). Although the apprentices do not enter the labour market after two years, the programmes contribute to their inclusion by reducing dropout from upper secondary education as they offer a strongly practice-oriented training from the start of VET and lead to a partial qualification. Step-by-step qualifications may enhance learning motivation and self-efficacy through regular feedback and assessment of achievement (e.g. Pilz 2012). The interviewees emphasised that these two characteristics are the main benefit of two-year apprenticeships.

As two-year apprenticeships in Norway were nationally introduced only since 2016 and are not yet broadly implemented, it showed in the interviews that the respective curricula in counties and fields with very few apprentices were so far highly individualised. Individualised curricula may allow to integrate learners in a specific work environment but they hardly promote labour market integration and mobility. This was shown in Switzerland, where the former, individualised two-year programmes were criticised for promoting workplace-integration rather than labour marketintegration as well as for not being permeable to the more demanding VET programmes - two reasons for which they were replaced by the nationally standardised two-year apprenticeships (Kammermann 2017).

Despite these differences regarding the main intention, this study shows that the criteria (dimensions) for developing the in-company part of the two-year curricula are largely the same in both countries. Commonalities are found in the dimensions 'occupation-specific core elements', 'reducing complexity' and 'limiting accountability and autonomy' (Billett 2001; Gherardi et al. 1998; Lave 1990). Lower performance requirements in two-year curricula are defined by choosing core elements and by reducing the complexity of work tasks which implies that autonomy and accountability are limited. The differences found in the dimensions 'considering the economic setting', 'reducing the scope of the occupational profile' and 'work- vs. school-based goals' are related to the overall conception of two-year apprenticeships (stand-alone occupation vs. partial qualification), to the structure of the VET systems and to educational policy goals.

To sum up, the fact that the certificates have a different value in both countries, but also the much longer implementation phase in Switzerland, may be responsible for the strongly differing number of participants in two-year apprenticeships. Further, the twoyear apprenticeships in Switzerland replaced former low-level programmes whereas in Norway they were added to the existing lower-level programmes (training candidate scheme). The survey part of the Norwegian study shows that this led many counties to refrain from implementing the new two-year apprenticeship so far.

The following critical questions remain to be answered: What kind of balance between economic and social goals in low-threshold apprenticeships is needed for the future? Switzerland balances employability with a full certification and permeability 
by crediting a year to the more demanding VET programmes. But will there still be a demand for such low-level occupations in tomorrow's world of work in which upskilling and transferable competences will be increasingly important? Norway opts for practice-oriented training without aiming at direct labour market integration after two years but puts more emphasis on general education to ensure permeability to the regular VET programmes by fully crediting the two years if the apprentices continue. Is this approach more promising for the future? And will it prevent dropout during the second stage of training?

\section{Limitations of the Study and Outlook}

The findings presented are limited for several reasons. In Norway two-year apprenticeships are nationally implemented only since 2016 and the experiences are still restricted to a few counties and apprentices and therefore very limited. However, all the responsibles who so far conceptualised and implemented two-year apprenticeships could be interviewed. Also in Switzerland, the interview basis is rather limited. Another limitation is that we could not include a systematic document study to compare two-year curricula of both countries. This could be the aim of a next research step. Further research could also integrate more countries with similar low-level VET programmes. Also, deeper comparative analyses of the processes of learning, guidance and instruction in companies would be interesting in two-year apprenticeships. For the question of stand-alone or partial qualifications, the transition and long-term integration into the labour market would be important issues for further research. Finally, we need more insight into the successful inclusion of youth at risk by means of different, more flexible pathways.

Acknowledgments We thank the Swiss-European Mobility Programme MOVETIA - for financially supporting research stays in Oslo for Ursula Scharnhorst and Marlise Kammermann.

Availability of Data and Material All data and materials as well as software application or custom code support the published claims and comply with field standards.

Code Availability custom code.

Funding Information Open Access funding provided by OsloMet - Oslo Metropolitan University. The Swiss-European Mobility Programme MOVETIA supported research stays in Oslo for Ursula Scharnhorst and Marlise Kammermann.

\section{Compliance with Ethical Standards}

Conflicts of Interest/Competing Interests The authors declare that they have no conflict of interest.

Open Access This article is licensed under a Creative Commons Attribution 4.0 International License, which permits use, sharing, adaptation, distribution and reproduction in any medium or format, as long as you give appropriate credit to the original author(s) and the source, provide a link to the Creative Commons licence, and indicate if changes were made. The images or other third party material in this article are included in the article's Creative Commons licence, unless indicated otherwise in a credit line to the material. If material is not included in the article's Creative Commons licence and your intended use is not permitted by statutory regulation or exceeds the permitted use, you will need to obtain permission directly from the copyright holder. To view a copy of this licence, visit http://creativecommons.org/licenses/by/4.0/. 


\section{References}

Becker, M., Kammermann, M., Spöttl, G., \& Balzer, L. (Eds.). (2017a). Ausbildung zum Beruf. Internationaler Vergleich der berufsförmigen Ausbildungskonzepte für benachteiligte Jugendliche. Frankfurt am Main: Peter Lang. https://doi.org/10.3726/978-3-653-06625-8.

Becker, M., Musekamp, F., \& Spöttl, G. (2017b). Berufsausbildung mit gemindertem Ausbildungsniveau in drei Ländern im Vergleich. In M. Becker, M. Kammermann, G. Spöttl, \& L. Balzer (Eds.), Ausbildung zum Beruf. Internationaler Vergleich der berufsförmigen Ausbildungskonzepte für benachteiligte Jugendliche (pp. 93-141). Frankfurt am Main: Peter Lang. https://doi.org/10.3726/978-3-653-06625-8.

BFS (2018). Quote der Erstabschlüsse auf der Sekundarstufe II und Maturitätsquote. Neuchâtel: Bundesamt für Statistik.

BFS (2019). Berufliche Grundbildung - Lehrverhältnisse. https://www.bfs.admin. $\mathrm{ch} / \mathrm{bfs} / \mathrm{de} /$ home/statistiken/bildung-wissenschaft/personen-ausbildung/sekundarstufe-II/beruflichegrundbildung-lehrverhaeltnisse.html. Access 25 Februar 2020.

Billett, S. (2000). Guided learning at work. Journal of Workplace Learning, 12(7), 272-285. https://doi. org/10.1108/13665620010353351.

Billett, S. (2001). Learning in the workplace: Strategies for effective practice. Sydney: Allen \& Unwin.

Billett, S. (2006). Constituting the workplace curriculum. Journal of Curriculum Studies, 38(1), 31-48. https://doi.org/10.1080/00220270500153781.

Billett, S. (2011). Vocational education. Purposes, traditions and prospects. Dordrecht: Springer Netherlands. https://doi.org/10.1007/978-94-007-1954-5.

Canning, R. (1998). The failure of competence-based qualifications: An analysis of work-based vocational education policy in Scotland. Journal of Education Policy, 13(5), 625-639. https://doi.org/10.1080 /0268093980130503.

Cedefop (2015). The role of modularisation and unitisation in vocational education and training. Cedefop working paper; no 26. Luxembourg: Publications Office of the European Union.

Chan, S. (2017). The reciprocity of "imitative learning" through apprenticeship. Vocations and Learning, 10(3), 325-342. https://doi.org/10.1007/s12186-017-9175-x.

Colley, H., James, D., Diment, K., \& Tedder, M. (2003). Learning as becoming in vocational education and training: Class, gender and the role of vocational habitus. Journal of Vocational Education \& Training, 55(4), 471-449. https://doi.org/10.1080/13636820300200240.

Collins, A., Brown, J. S., \& Newman, S. E. (1989). Cognitive apprenticeship: Teaching the craft of reading, writing, and mathematics. In L. B. Resnick (Ed.), Knowing, learning, and instruction: Essays in honor of Robert Glaser (pp. 453-494). Hillsdale, NJ: Lawrence Erlbaum Associates. https://doi.org/10.4324 /9781315044408-14.

Dehnbostel, P., \& Schröder, T. (2017). Work-based and work-related learning - Models and learning concepts.TVET@Asia, 9, 1-12.

Der Bundesrat (2019). Einführung des Eidgenössischen Berufsattests - Eine Bilanz. Bern: Schweizerische Eidgenossenschaft.

European Commission (2020). Find and compare qualifications frameworks. https://ec.europa. eu/ploteus/en/compare. Access 25 February 2020.

Di Maio, G., Graf, L., \& Wilson, A. (2019). Torn between economic efficiency and social equality? Shorttrack apprenticeships in Denmark, Germany and Switzerland. European Educational Research Journal, 18(6), 699-723. https://doi.org/10.1177/1474904119869561.

Fuller, A. (2016). Developing expertise: Occupational versus job-based approaches in contemporary labour markets. In J. Seifried, S. Seeber, \& B. Ziegler (Eds.), Jahrbuch der berufs- und wirtschaftspädagogischen Forschung 2016 (pp. 11-22). Berlin: Verlag Barbara Budrich. https://doi. org/10.2307/j.ctvbkjztw.4.

Gherardi, S., Nicolini, D., \& Odella, F. (1998). Toward a social understanding of how people learn in organizations: The notion of situated curriculum. Management Learning, 29(3), 273-297. https://doi. org/10.1177/1350507698293002.

Ghisla, G. (2005). Modularisierung der Bildung: Flexibilität, aber zu welchem Preis? Schweizerische Zeitschrift für Bildungswissenschaften, 27(2), 157-174.

Gibbs, G. R. (2018). Analyzing qualitative data. London: SAGE.

Gonon, P. (2009). Modularisierung als Transformationsperspektive. In M. Pilz (Ed.), Modularisierungsansätze in der Berufsbildung. Deutschland, Österreich sowie Grossbritannien im Vergleich (pp. 83-94). Bielefeld: Wbv. 
Gonon, P. (2014). What makes the dual system to a dual system? A New Attempt to Define VET through a Governance Approach. In bwp@Berufs- und Wirtschaftspädagogik-Online, Ausgabe Nr. 25, 1-13. Online: http://www.bwpat.de/ausgabe25/gonon_bwpat25.pdf.

Häfeli, K. (2005). Modularisierung in der Berufsausbildung: Eine chance für behinderte und benachteiligte Jugendliche? In K. Felkendorff \& E. Lischer (Eds.), Barrierefreie Übergänge? Jugendliche mit Behinderungen und Lernschwierigkeiten zwischen Schule und Erwerbsarbeit (pp. 104-113). Zürich: Pestalozzianum.

Hatano, G., \& Inagaki, K. (1986). Two courses of expertise. In H. W. Stevenson, H. Azuma, \& K. Hakuta (Eds.), Child development and education in Japan (pp. 262-272). New York: W. H. Freeman.

Hodkinson, P., Biesta, G., \& James, D. (2008). Understanding learning culturally: Overcoming the dualism between social and individual views of learning. Studies in Vocational and Professional Education, 1(1), 27-47. https://doi.org/10.1007/s12186-007-9001-y.

Høst, H. (2016). Praksisbrev i arbeidslivet - Et vellykket tiltak mot frafall. In K. Reegård \& J. Rogstad (Eds.), De Frafalne. Om frafall i videregående opplaring - Hvem er de, hva vil de og hva kan gjøres? (pp. 173198). Gyldendal akademisk: Oslo.

INAP Commission (2012). Memorandum: An architecture for modern apprenticeships - Standards for structure, organization and governance. Switzerland: University of Zurich.

Kammermann, M. (2017). Die Entwicklung der zweijährigen beruflichen Grundbildungen mit Eidgenössischem Berufsattest (EBA) in der Schweiz. In M. Becker, M. Kammermann, G. Spöttl, \& L. Balzer (Eds.), Ausbildung zum Beruf. Internationaler Vergleich der berufsförmigen Ausbildungskonzepte für benachteiligte Jugendliche (pp. 11-28). Frankfurt am Main: Peter Lang.

Kammermann, M., Stalder, B. E., \& Hättich, A. (2011). Two-year apprenticeships - A successful model of training? Journal of Vocational Education \& Training, 63(3), 377-396. https://doi.org/10.1080 /13636820.2011.586130.

Krathwohl, D. R., Bloom, B. S., \& Masia, B. B. (1964). Taxonomy of educational objectives: Handbook II: The affective domain. New York: McKay.

Kunnskapsdepartementet (2006). Tiltak for bedre gjennomføring i videregående opplæring. Rapport Arbeidsgruppe nedsatt av Kunnskapsdepartementet. Oslo: Kunnskapsdepartementet.

Lamb, S. (2011). Pathways to school completion: An international comparison. In S. Lamb, E. Markussen, R. Teese, N. Sandberg, \& J. Polesel (Eds.), School dropout and completion: International comparative studies in theory and policy (pp. 21-73). Dordrecht: Springer. https://doi.org/10.1007/978-90-481-97637.

Lave, J. (1990). The culture of acquisition and the practice of understanding. In J. W. Stigler, R. A. Shweder, \& G. H. Herdt (Eds.), Cultural psychology. Essays on comparative human development (pp. 309-327). Cambridge: Cambridge University Press. https://doi.org/10.1017/CBO9781139173728.010.

Lave, J. (2011). Apprenticeship in critical ethnographic practice. Chicago: The University of Chicago Press. https://doi.org/10.7208/chicago/9780226470733.001.0001.

Lave, J., \& Wenger, E. (1991). Situated learning: Legitimate peripheral participation. Cambridge: Cambridge University Press. https://doi.org/10.1017/CBO9780511815355.

Li, J., \& Pilz, M. (2017). Modularisation in the German VET system: A study of policy implementation. Journal of Education and Work, 30(5), 471-485. https://doi.org/10.1080/13639080.2016.1243233.

Nyen, T., Skålholt, A., \& Tønder, A. H. (2015). Vocational education and school to work transitions in Norway. In S. Bohlinger, U. Haake, C. H. Jørgensen, H. Toiviainen, \& A. Wallo (Eds.), Working and learning in times of uncertainty. Challenges to adult, professional and vocational education (pp. 173182). Rotterdam: Sense Publisher. https://doi.org/10.1007/978-94-6300-244-8_13.

OECD (2018a). Education at a Glance 2018. OECD indicators. Paris: OECD.

OECD (2018b). Seven questions about apprenticeships: Answers from international experience. Paris: OECD

Pilz, M. (2012). Modularisation of vocational training in Germany, Austria and Switzerland: Parallels and disparities in a modernisation process. Journal of Vocational Education \& Training, 64(2), 169-183. https://doi.org/10.1080/13636820.2011.628757.

Pilz, M., \& Canning, R. (2017). The modularisation approach of work-based VET in Scotland. Journal of Education and Work, 30(7), 722-730. https://doi.org/10.1080/13639080.2017.1383095.

Rauner, F. (2007). Practical knowledge and occupational competence. European Journal of Vocational Training, 40(1), 52-66.

Rauner, F. (2012). Stabile Kernberufe fördern die Flexibilität der Fachkräfte. Panorama, 15, 15.

Reegård, K. (2015). Sales assistants in the making: Learning through responsibility. Vocations and Learning, 8(2), 117-133. https://doi.org/10.1007/s12186-015-9129-0.

Rogoff, B. (1995). Observing sociocultural activity on three planes: Participatory appropriation, guided participation, and apprenticeship. In J. V. Wertsch, P. Del Rio, \& A. Alvarez (Eds.), Sociocultural studies 
of mind (pp. 139-164). Cambridge: Cambridge University Press. https://doi.org/10.1017 /CBO9781139174299.008.

SBFI (2017). Prozess der Berufsentwicklung in der beruflichen Grundbildung. Handbuch. Bern: SBFI.

Schmid, E. (2020). Upper secondary education for youth at risk: A comparative analysis of education and training Programmes in Austria, Norway, Sweden and Switzerland. International Journal for Research in Vocational Education and Training, 7(1), 21-44. https://doi.org/10.13152/10.13152/IJRVET.7.1.2.

Seufert, S. (2018). Flexibilisierung der Berufsbildung im Kontext fortschreitender Digitalisierung. Bericht im Auftrag des Staatssekretariats für Bildung, Forschung und innovation SBFI im Rahmen des Projekts «Berufsbildung 2030 - Vision und Strategische Leitlinien». Bern: SBFI.

Swiss Confederation (2002). Vocational Training Act. Bundesgesetz über die Berufsbildung vom 13. Dezember 2002. Bundeskanzlei.

Utdanningsdirektoratet (2017). Praksisbrev. Oslo: Utdanningsdirektoratet.

Van den Akker, J. (2003). Curriculum perspectives: An introduction. In J. Van den Akker, W. Kuiper, \& U. Hameyer (Eds.), Curriculum landscapes and trends (pp. 1-10). Dordrecht: Springer Science + Business Media. https://doi.org/10.1007/978-94-017-1205-7_1.

Wenger, E. (1998). Communities of practice: Learning, meaning, and identity. Cambridge: Cambridge University Press. https://doi.org/10.1017/CBO9780511803932.

Wettstein, E., Schmid, E., \& Gonon, P. (2017). Swiss Vocational and Professional Education and Training (VPET). Forms, System, Stakeholders. Berne: Hep.

Zbinden, A. (Ed.). (2010). Berufe reformieren und weiterentwickeln. Ein handlungskompetenzorientierter Ansatz. Bern: hep.

Publisher's Note Springer Nature remains neutral with regard to jurisdictional claims in published maps and institutional affiliations.

Evi Schmid, PhD, is an educational scientist and associate professor at the Department of Vocational Teacher Education at OsloMet - Oslo Metropolitan University, Norway. Her research interests include school-to-work transitions, dropout from VET, alternative training pathways for youth at risk, social inclusion and education policy.

Ursula Scharnhorst, $\mathrm{PhD}$, is an educational scientist and professor at SFIVET - Swiss Federal Institute for Vocational Education and Training, Switzerland. Her research interests include learning and cognition in youth with learning difficulties or disabilities, learning strategies and metacognition.

Marlise Kammermann, $\mathrm{PhD}$, is a senior lecturer and senior researcher at SFIVET - Swiss Federal Institute for Vocational Education and Training, Switzerland. Her research and teaching interests include school-towork transitions, VET programmes for low achievers and youth at risk, support and guidance of learners, inclusion.

\section{Affiliations}

\section{Evi Schmid ${ }^{1}$ • Ursula Scharnhorst ${ }^{2}$ - Marlise Kammermann ${ }^{2,3}$}

1 Department of Vocational Teacher Education, Oslo Metropolitan University, Oslo, Norway

2 Department of Research \& Development, Swiss Federal Institute for Vocational Education and Training SFIVET, Zollikofen, Switzerland

3 Department of Basic Training, Swiss Federal Institute for Vocational Education and Training SFIVET, Zollikofen, Switzerland 